\title{
Chlorinated Dioxin and Furan Congener Profiles from Pentachlorophenol Sources
}

\author{
Glenn W. Johnson \\ Energy \& Geosciences Institute, University of Utah, Salt Lake City, USA \\ Email: gjohnson@egi.utah.edu
}

How to cite this paper: Johnson, G.W. (2017) Chlorinated Dioxin and Furan Congener Profiles from Pentachlorophenol Sources. Journal of Environmental Protection, 8, 663-677. https://doi.org/10.4236/jep.2017.86043

Received: May 9, 2017

Accepted: June 24, 2017

Published: June 27, 2017

Copyright $\odot 2017$ by author and Scientific Research Publishing Inc. This work is licensed under the Creative Commons Attribution International License (CC BY 4.0).

http://creativecommons.org/licenses/by/4.0/ (c) (i) Open Access

\begin{abstract}
Pentachlorphenol (PCP) was widely used as a biocide and insecticide for wood preservation. Chlorinated dioxins and furans (2,3,7,8-substituted PCDD and PCDF congeners) were inadvertent byproducts of PCP production. As such, it is an important source of PCDD/F contamination in treated wood and in soil/ sediment near sites that produced or used PCP. It has been noted in the literature, that PCP congener profiles are similar to some combustion profiles, as well as sewage sludge and particulate deposition. In a very broad sense, this is true. OCDD and 1,2,3,4,6,7,8-HpCDD are typically the dominant constituents in these source categories. There is however, a distinct, consistent and repeatable feature in the lower chlorinated tetra, penta and hexa PCDD/F range of PCP related samples: an order of magnitude increase in concentration as a function of degree of chlorination. Because lower chlorinated furans concentrations make up less than $1 \%$ of the total $\mathrm{PCDD} / \mathrm{F}$ in $\mathrm{PCP}$, it is difficult to differentiate PCP from other OCDD dominated source profiles on bar-graphs that use a linear-scale y axis. Using a log-scale y axis, however, PCP impacted profiles are obvious, and are not easily confused with congener profiles from other sources.
\end{abstract}

\section{Keywords}

Pentachlorophenol, Polychlorinated Dibenzofurans, Polychlorinated Dibenzo-p-Dioxins

\section{Introduction}

Pentachlorophenol (PCP) is a biocide used extensively in Europe, North American and elsewhere. It was used primarily for wood treatment, but also as a contact herbicide and other pesticide applications [1] [2] [3] [4]. Its use for these applications began in the 1930s [2]. It was produced by two methods: catalytic chlorination of phenol and hydrolysis of hexachlorobenzene [1] [2] with the 
former being the primary method used in the United States [2]. PCP was produced under a number of trade names, including Santophen (Monsanto), Witophen P (Dynamit Nobel), and Dowicide 7 (Dow) [1] [3] [4]. Precise global PCP production numbers are not known [1] [9] [37] but reported estimates range between 30,000 [37] to 90,000 metric tons per year [38] through the 1970s with production and use decreasing in the 1980s due to restrictions/regulations and increasing use of alternative methods of wood preservation [1] [37].

Technical-grade pentachlorophenol contains a considerable amount of impurities, such that the product typically sold as "pentachlorophenol" was only about 90\% - 92\% PCP [1]. The most abundant impurities are lower chlorinated phenols (e.g. tetrachlorophenol makes up 4\% - 9\% of technical PCP, and trichlorophenol <0.1\%) [1]. Polychlorinated dibenzofurans (PCDF) and dibenzo-pdioxins (PCDD) are also present in technical grade PCP products [5] [6] [7] [8]. Figure 1 shows two reactions that lead to the two most abundant PCDD and PCDF impurities in PCP: octachlorinated dibenzo-p-dioxin (OCDD) andoctachlorinated dibenzofuran (OCDF).

Typical PCDD/F concentrations observed in PCP are in the range of 0.5 to 2 $\mathrm{mg} / \mathrm{kg}$ (ppm) TEQ [9], where TEQ is the weighted toxicity equivalence of the 17 2,3,7,8 $\mathrm{PCDD} / \mathrm{F}$ congener concentrations [10]. While this is a trace amount as compared to other impurities in PCP, when viewed in context of a typical $\mathrm{PCDD} / \mathrm{F}$ residential cleanup/action levels (0.00001 - $0.0015 \mathrm{ppm})$ [11], PCP can be an important source of PCDD/F in treated wood and in soil/sediment near wood treatment facilities and PCP manufacturing sites [12] [13] [14] [15].

Previous studies have addressed the congener profiles of pentachlorophenol as compared to those from other sources [20] [21] [22], and have suggested that the

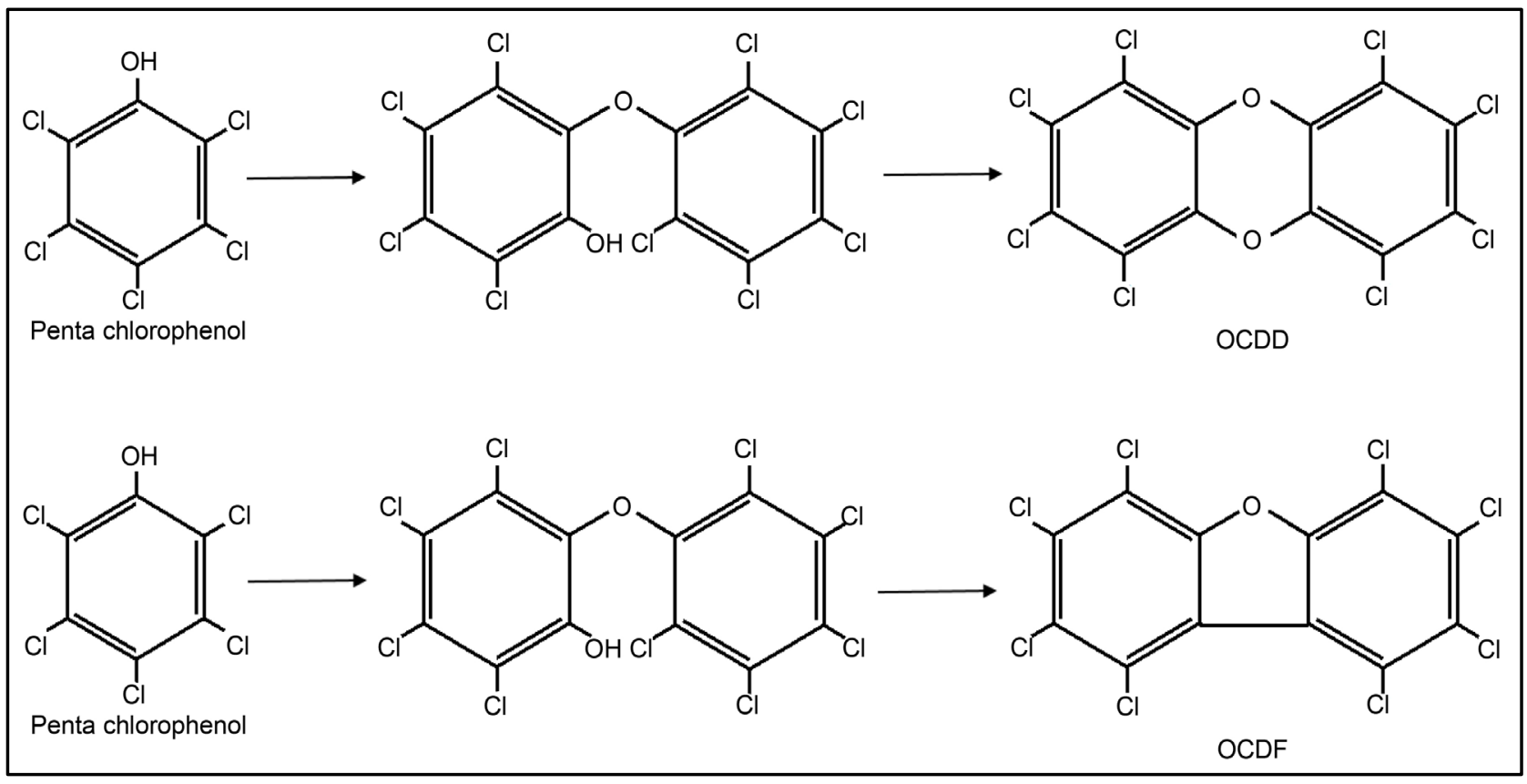

Figure 1. Pentachlorophenol Molecule (left on both panels) and chemical reactions that lead to formation of octachlorodibenzo-p-dioxin (OCDD, upper panel) and octachlorodibenzofuran (OCDF, lower panel). After Plimmer [8]. 
congener profile of PCP is similar to some combustion sources (diesel truck emissions, unleaded gasoline vehicle emissions, and industrial wood combustion [22]) as well as sewage sludge and atmospheric deposition [20] [21]. These studies point to the dominance of OCDD (typically $70 \%-90 \%$ of the sum of 17 2,3,7,8 substituted congeners in $\mathrm{PCP}$ ) as the key chemical characteristic leading to that conclusion.

The objective of this paper is to characterize the congener profiles of 2,3,7,8 substituted PCDDs and PCDFs, present as impurities in technical grade PCP, as a result of its production [4] [5] [6] [7] [8] [9]. It should be noted that there is a second way that PCDD/F may be associated with PCP: de novo formation of OCDD from a pentachlorophenol precursor, either in the atmosphere or as a biochemical reaction in sewage sludge [16] [17] [18] [19]. This paper however, focuses on the PCDD/F congener profile observed as impurities in technical-grade PCP. The data examined here are the seventeen 2,3,7,8-substutituted congeners, and this focus is primarily a function of data availability. This paper relies on published and publically available data, and while full-congener analysis of all PCDD/F congeners (75 PCDD congeners, 135 PCDF congeners) is an emergent analytical method [23] the vast majority of available dioxin data reported in the literature have been analyzed for the 17 2,3,7,8-substituted PCDD/ Fs.

\section{PCDD and PCDF in Technical Pentachlorophenol}

There have been a few studies that have reported concentrations of the $172,3,7,8$ substituted PCDD/F congeners in technical PCP product [9] [24] [25] [26]. Unfortunately, these analyses of dioxins in PCP were conducted more than 20 years ago, and there are issues with some congeners reported below method detection limits (non-detects). In terms of numbers of non-detects, the best of these was a 1987 study by Hagenmaier and Brunner [9]. PCDD/F congener data were reported for technical PCP products from two different manufacturers. But by the standard of current PCDD/F analytical methods, these data have some issues: 1) five of the 17 congeners were reported below detection limits; and 2) coelutions were reported for the two pentachlorinated CDFs. The congener profiles for these two samples is shown on Figure 2. On this and subsequent bar-graphs, non-detects are indicated with a " $U$ " qualifier at the top of the bar, coeluting peaks with a " $\mathrm{C}$ " qualifier. The chemical characteristic that is most striking on this figure is the dominance of OCDD, which is greater than $70 \%$ of the sum the 17 variables. This OCDD dominance in PCP congener profiles has been noted by others and is the primary reason for studies that have concluded that that PCP profile is similar to other source patterns [20] [21] [22].

Plotting these bar-graphs using a linear y-axis scale shows the obvious dominance of OCDD, and the secondary levels of OCDF and hepta-chlorinated congeners. It provides little insight however, into any differences in relative concentrations of tetra, penta and hexa chlorinated CDD/Fs. These lower chlorinated congeners all look to be essentially at or near the zero line on the $y$-axis. 


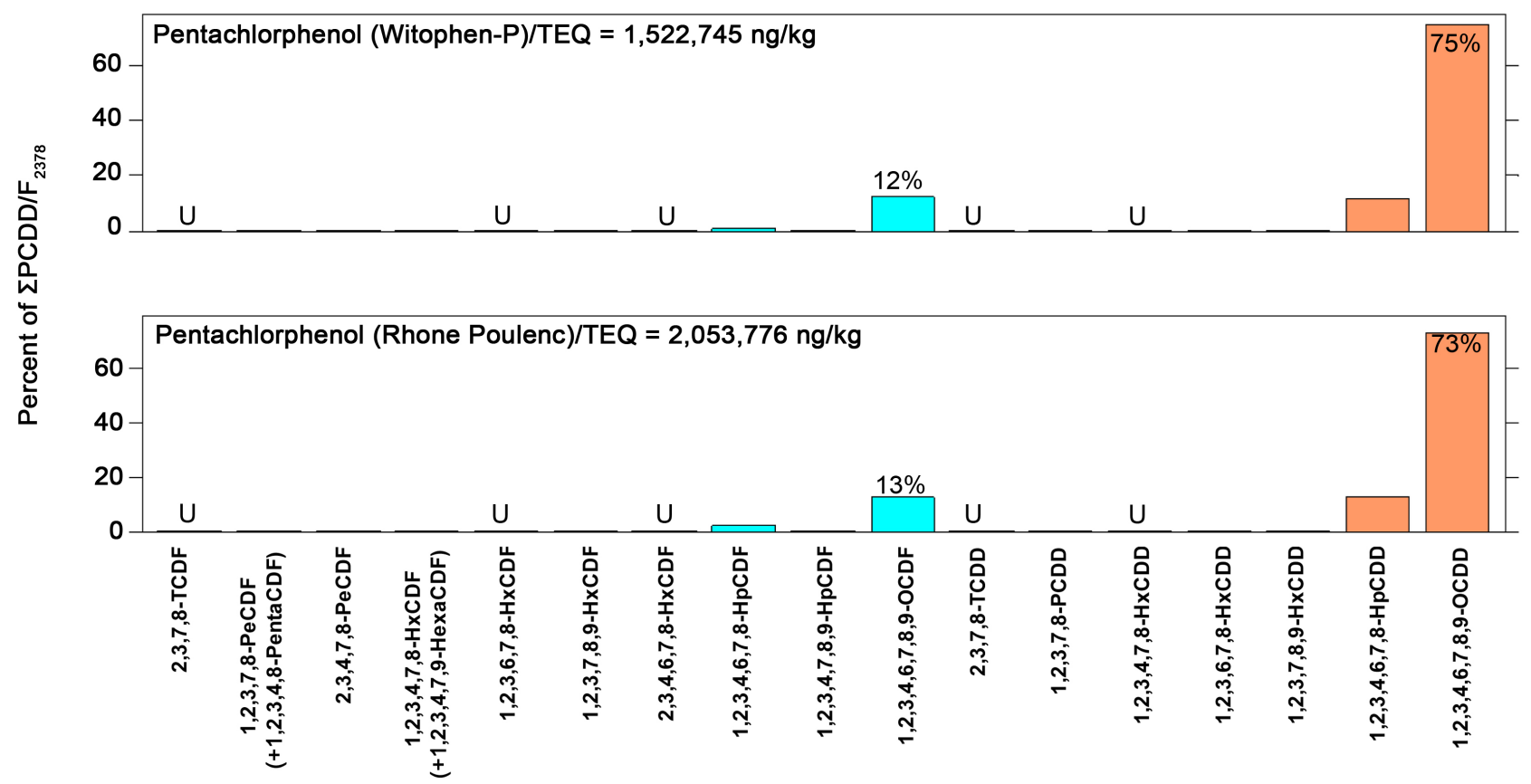

Figure 2. Pentachlorophenol congener profiles (bar-graphs) for two PCP products reported by Hagenmaier and Brunner (1987) [9] plotted with a linear y-scale. TEQ calculated using WHO 2005 TEFs [10]. "U” indicates non-detect. "C" indicates coeluting analyte.

To the extent that there is anything diagnostic in the lower chlorinated congeners, it is not visible on bar-graph with a linear-scale y-axis.

Figure 3 shows bar-graphs for the same two PCP samples/profiles, except that they are plotted with a log scale $y$-axis. On the log-scale graph, it is apparent that there is a great deal of contrast within the lower chlorinated congeners. The HxCDDs and HxCDFs (hexa-chlorinated congeners) while orders of magnitude lower in concentration than OCDD and OCDF, are orders of magnitude higher than tetra and penta dioxins and furans.

Figure 4 shows the congener profile for one of the two technical PCP samples discussed above in comparison to the congener profiles from other PCP impacted media (sediment [12], soil [14], PCP treated railway ties wood [27], and PCP treated utility poles [28]). All of these profiles exhibit a similar pattern, with the relative concentration of both PCDD and PCDF congeners increasing by one to two orders of magnitude as a function of degree of chlorination. This makes sense when viewed in context of impurities reported in technical PCP, and the chemical reactions that produce PCDD/F in PCP production (Figure 1). NTP (1989) [1] reported lower chlorinated chlorophenol impurities in commercial pentachlorophenol samples, such that tetrachlorophenol $\gg$ trichlorophenol $\gg$ dichlorophenol. If these lower chlorinated phenol impurities substitute for PCP in the chemical reactions shown in Figure 1 (and in similar proportions to their relative concentrations in technical PCP), it is logical that levels of tetra, penta, hexa and hepta PCDD/F would exhibit increasing concentrations in PCP as a function of degree of chlorination.

Note also on Figure 3 and Figure 4 that within the hexa-chlorinated diben- 


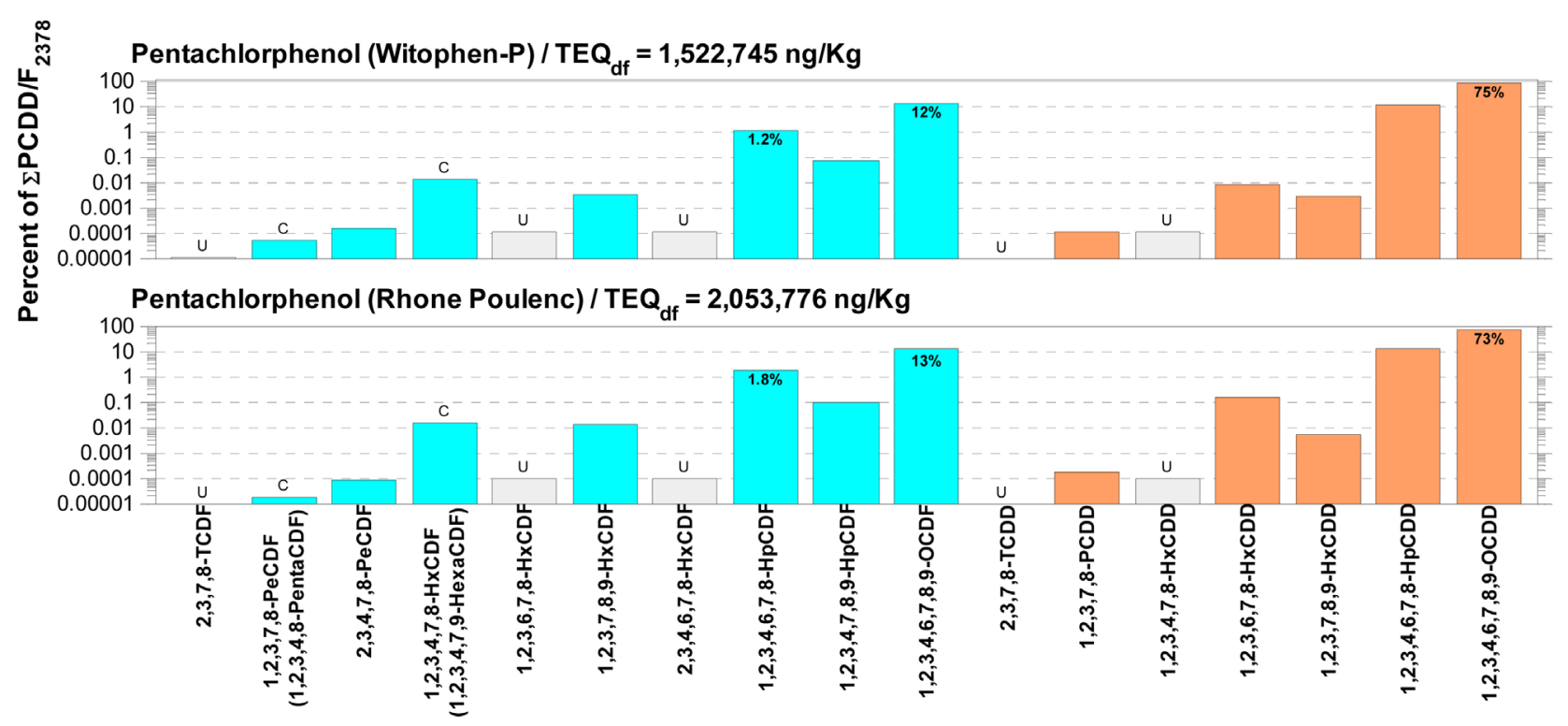

Figure 3. Pentachlorophenol congener profiles (bar-graphs) for two PCP products reported by Hagenmaier and Brunner (1987) [9] plotted with a log y-scale. TEQ calculated using WHO 2005 TEFs [10]. "U" qualifier and gray shading indicates non-detect. "C" indicates coeluting analyte.

zofurans, 1,2,3,4,7,8-HxCDF (fourth bar from the left) is consistently the highest. This is typical of PCP related congener profiles. For purposes of this graphic, I have taken one sample from each of these studies. But this characteristic PCP pattern is consistent for the majority of PCP impacted samples from the literature that I have reviewed.

There are however exceptions. A study by Masunaga et al. [29] reported concentrations of 17-2,3,7,8 PCDD/F congeners in four Japanese PCP samples. The samples were typical in that they were dominated by OCDD (with secondary $\mathrm{HpCDD}, \mathrm{OCDF}$, and $\mathrm{HpCDF}$ ) but for the lower chlorinated congener, the order of magnitude increase in concentration as a function of degree of chlorination was not observed. The reason the Japanese samples differ is not clear. Given that the majority of available data are from North America and Europe, it may be due to different pentachlorophenol production methods for Japanese formulations. Another exception to the typical pattern was noted in a 2010 study by Tondeur, et al., [30] who reported the average concentrations PCDD/F congeners from 20 PCP samples. In this study, the order of magnitude differences in concentration, as a function of degree of chlorination were as described here for the typical PCP pattern. However, OCDF ( $69 \%$ of $\Sigma \mathrm{PCDD} / \mathrm{F}$ ) was the dominant reported congener in their average PCP pattern, not OCDD (23\%).

\section{Graphical and Numerical Comparison of PCP Congener Profiles to Other Sources}

Previous studies have suggested that the congener profile of PCP is similar to those from a number of other sources. Cleverly, et al. [22] reported similarities to diesel truck emissions, unleaded gasoline vehicle emissions, and industrial wood combustion, citing the dominance of OCDD in observed on linear scale 

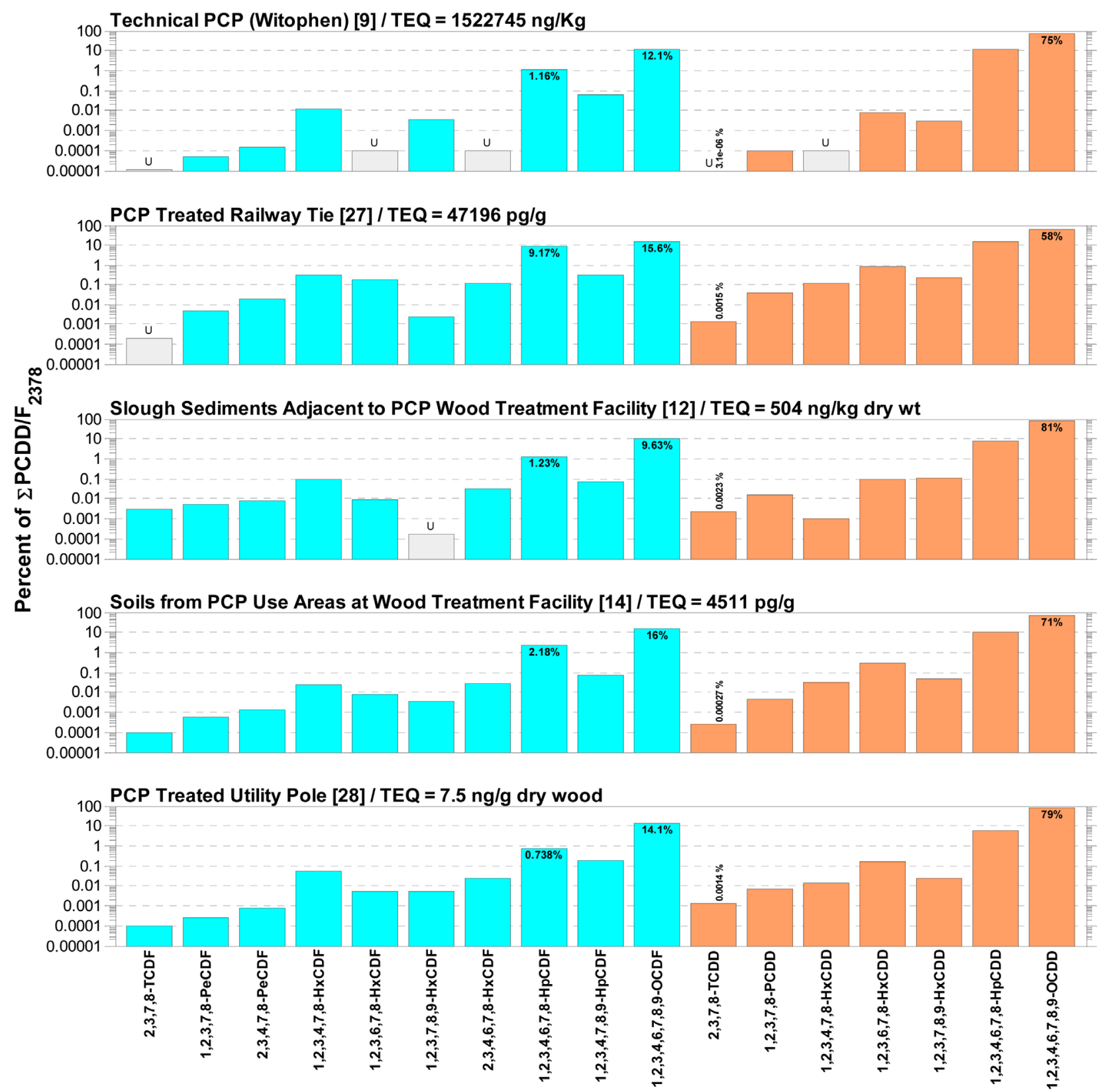

Figure 4. PCP congener profiles reported in various media (technical PCP product, soil, sediment, and treated wood).

bar-graphs. Hagenmaier, et al. [21] reported that PCP was similar to sewage sludge and atmospheric deposition, also pointing to the dominance of OCDD (typically $70 \%-90 \%$ of the sum of $172,3,7,8$ substituted congeners in PCP) as the key chemical characteristic leading to that conclusion.

Figure 5 shows a PCP impacted soil sample (top panel) in comparison to congener profiles from each these five other source categories, with a log-scale $\mathrm{y}$-axis. If one focuses on the relative proportion of OCDD, the congener patterns are indeed similar. OCDD is the most abundant PCDD/F congener in each.

The similarity between the six congener profiles shown on Figure 5 is also evident when quantified using a numerical similarity metric (Table 1). Correlation coefficients calculated between PCP and the other five congener profiles 

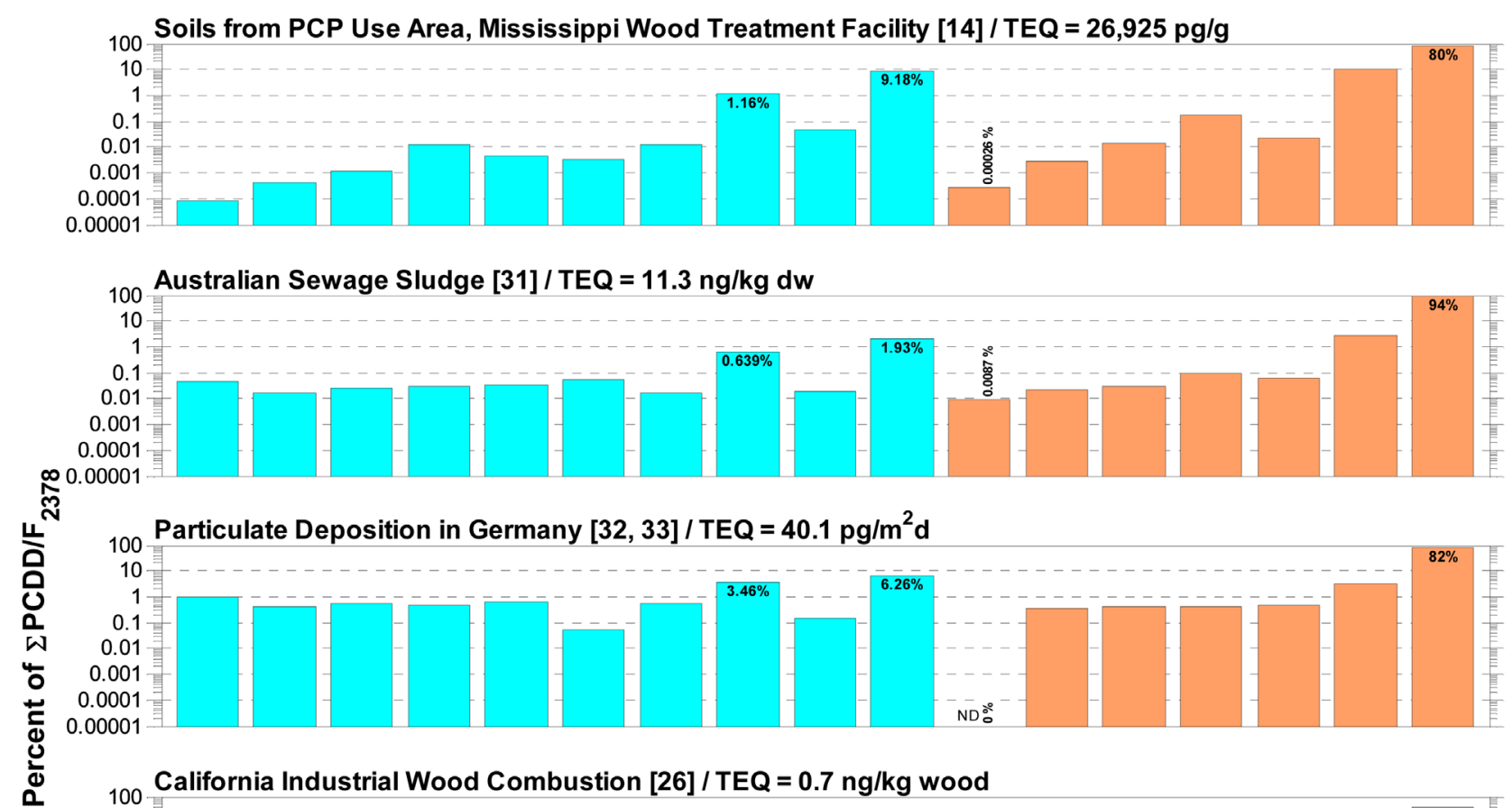

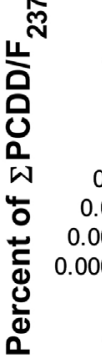
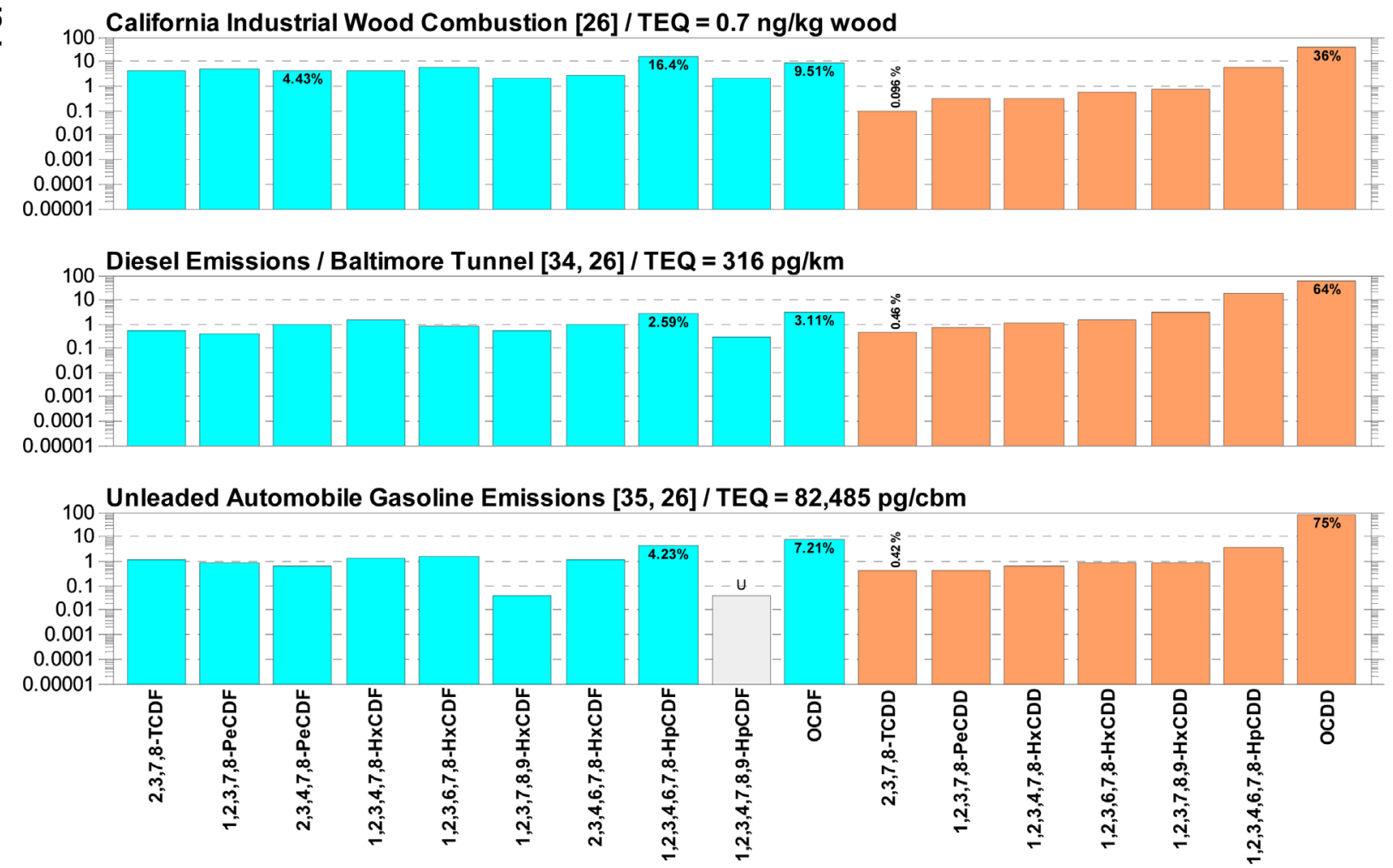

Figure 5. Congener profile of PCP impacted soil sample (top panel) in comparison to profiles from five other source categories which have been suggested in the literature to be similar to PCP. Data from [14] [26] [31] [32] [33] [34] [35].

shown on Figure 5 range from 0.90 to 1.0. That is because this metric applied to raw concentration data is strongly leveraged by OCDD which, in all of these samples, is much higher in concentration than any other congener. Not coincidentally, the sample with the lowest percent-OCDD (industrial wood combustion: $\mathrm{OCDD}=36 \%)$ is the sample with the lowest correlation coefficient $(0.90)$ when compared to PCP (Figure 5). One strategy that would allow the lower 
Table 1. Pearson correlation coefficients calculated between PCDD/F source category patterns shown on Figure 5.

\begin{tabular}{ccccccc}
\hline $\begin{array}{c}\text { Source Category } \\
\text { (Figure 5) }\end{array}$ & PCP & $\begin{array}{c}\text { Sewage } \\
\text { Sludge }\end{array}$ & $\begin{array}{c}\text { Particulate } \\
\text { Depostion }\end{array}$ & $\begin{array}{c}\text { Indust. } \\
\text { Wood } \\
\text { Combust. }\end{array}$ & $\begin{array}{c}\text { Diesel } \\
\text { Emissions }\end{array}$ & $\begin{array}{c}\text { Unl. Gas } \\
\text { Emissions }\end{array}$ \\
\hline PCP & 1.00 & & & & & \\
Sewage Sludge & 0.99 & 1.00 & & & & \\
Particulate Depostion & 0.99 & 1.00 & 1.00 & & & \\
$\begin{array}{c}\text { Industrial Wood } \\
\text { Combustion }\end{array}$ & 0.90 & 0.89 & 0.91 & 1.00 & & \\
$\begin{array}{c}\text { Diesel Emissions } \\
\text { Unleaded Gas } \\
\text { Emissions }\end{array}$ & 0.99 & 0.97 & 0.97 & 0.88 & 1.00 & \\
\hline
\end{tabular}

concentration congeners to have greater weight (and therefore allow greater contrast between PCP and non-PCP profiles) would be to log-transform the data prior to calculation of the correlation coefficient.

Another approach would be to use an alternative similarity metric. The Spearman correlation coefficientis based on correlation of the ranks of the 17 congener concentrations in each sample (Table 2). Like a log-transformation, this allows the lower concentrations congeners to have more weight. As such, the dissimilarity between PCP and other sources (that do not exhibit the order of magnitude differences in concentrations as a function of degree of chlorination) is better reflected by the lower Spearman similarity metrics (Table 2).

This is not meant to suggest that Spearman (or non-parametric statistical methods in general) are necessarily preferable for forensics applications. Rather, the Spearman metric is more effective in this particular instance, because by performing the correlation calculation on ranks (rather than raw concentrations) the lower concentration analytes are allowed to have more weight, and is therefore more effective in illustrating the contrast between PCP and other OCDD dominated congener profiles. An equally viable approach would be to use data transformations prior to the calculation of the Pearson correlation coefficients. Transformations such as log and/or autoscale (i.e. mean-center and scale) would allow the lower concentration congeners to have greater weight, and would therefore show greater contrast between OCDD-dominated PCP and non-PCP profiles. An illustration of the effectiveness of such transformations will be shown in the PCA application that follows [36].

\section{Implications for Multivariate Statistical Analysis}

The dominance of OCDD in these congener profiles has equally important implications for multivariate statistical analysis. Procedures such as principal components analysis (PCA) are variance-driven, and there is usually a strong relationship between the mean value of an analyte and its variance. To allow lower concentration variables to have equal weight in a PCA, it is often necessary to perform a log-transform and/or "homogeneity of variance" transformation 
Table 2. Spearman rank correlation coefficients calculated between PCDD/F source category patterns shown on Figure 5.

\begin{tabular}{|c|c|c|c|c|c|c|}
\hline $\begin{array}{l}\text { Source Category } \\
\text { (Figure 5) }\end{array}$ & PCP & $\begin{array}{l}\text { Sewage } \\
\text { Sludge }\end{array}$ & $\begin{array}{l}\text { Particulate } \\
\text { Depostion }\end{array}$ & $\begin{array}{l}\text { Indust. } \\
\text { Wood } \\
\text { Combust. }\end{array}$ & $\begin{array}{c}\text { Diesel } \\
\text { Emissions }\end{array}$ & $\begin{array}{l}\text { Unl. Gas } \\
\text { Emissions }\end{array}$ \\
\hline PCP & 1.00 & & & & & \\
\hline Sewage Sludge & 0.72 & 1.00 & & & & \\
\hline Particulate Depostion & 0.52 & 0.68 & 1.00 & & & \\
\hline $\begin{array}{l}\text { Industrial Wood } \\
\text { Combustion }\end{array}$ & 0.43 & 0.54 & 0.82 & 1.00 & & \\
\hline Diesel Emissions & 0.79 & 0.79 & 0.70 & 0.45 & 1.00 & \\
\hline $\begin{array}{l}\text { Unleaded Gas } \\
\text { Emissions }\end{array}$ & 0.56 & 0.62 & 0.91 & 0.82 & 0.71 & 1.00 \\
\hline
\end{tabular}

prior to the analysis [36]. PCA was run on a data set with $2,3,7,8-\mathrm{PCDD} / \mathrm{F}$ data from samples taken from four typical OCDD-dominated source categories discussed within this paper (PCP, diesel emissions, sewages sludge and particulate deposition). For the PCA scores plot shown in the upper panel of Figure 6, the data were normalized to percent of total PCDD/F concentration. Samples from all four source categories plot in close proximity to each other, suggesting that these profiles are similar. This is because with only percent transformation, high proportions of OCDD dominate the analysis.

In the second panel on Figure 6, the data have been sample-normalized (percent), then log-transformed, then autoscaled (mean-centering across variables, followed by division by the standard deviation). These transformations have the effect to giving the low concentration congeners more weight in the analysis [36], and as a result, there is clear separation of the PCP related samples from the other OCDD dominated source categories.

In addition to PCA, it is instructive to look at this data set in terms of numerical similarity metrics discussed earlier. Table 3 shows the Spearman coefficients for the 35 samples used for the two PCA runs shown on Figure 6. All PCP samples have Spearman values $\geq 0.92$; none of the samples from the other source categories have a Spearman value $>0.86$, with respect to PCP. Most are less than 0.65 .

\section{Discussion}

The dominance of OCDD in Pentachlorophenol is such that the typical PCP congener profile is similar to those from sewage sludge, atmospheric deposition, and some combustion sources, in that all of these source categories typically exhibit a predominant OCDD pattern. However, PCP can be readily distinguished from the congener profiles of these other sources. The diagnostic part of the PCP profile lies within the order of magnitude lower concentration tetra, penta and hexa PCDD/Fs. 2,3,7,8-TCDD and 2,3,7,8-TCDF are present in PCP impacted samples. For both dioxins and furans in PCP, congeners with 8 chlorines are 


\section{Sample Normalization Only (Percent)}

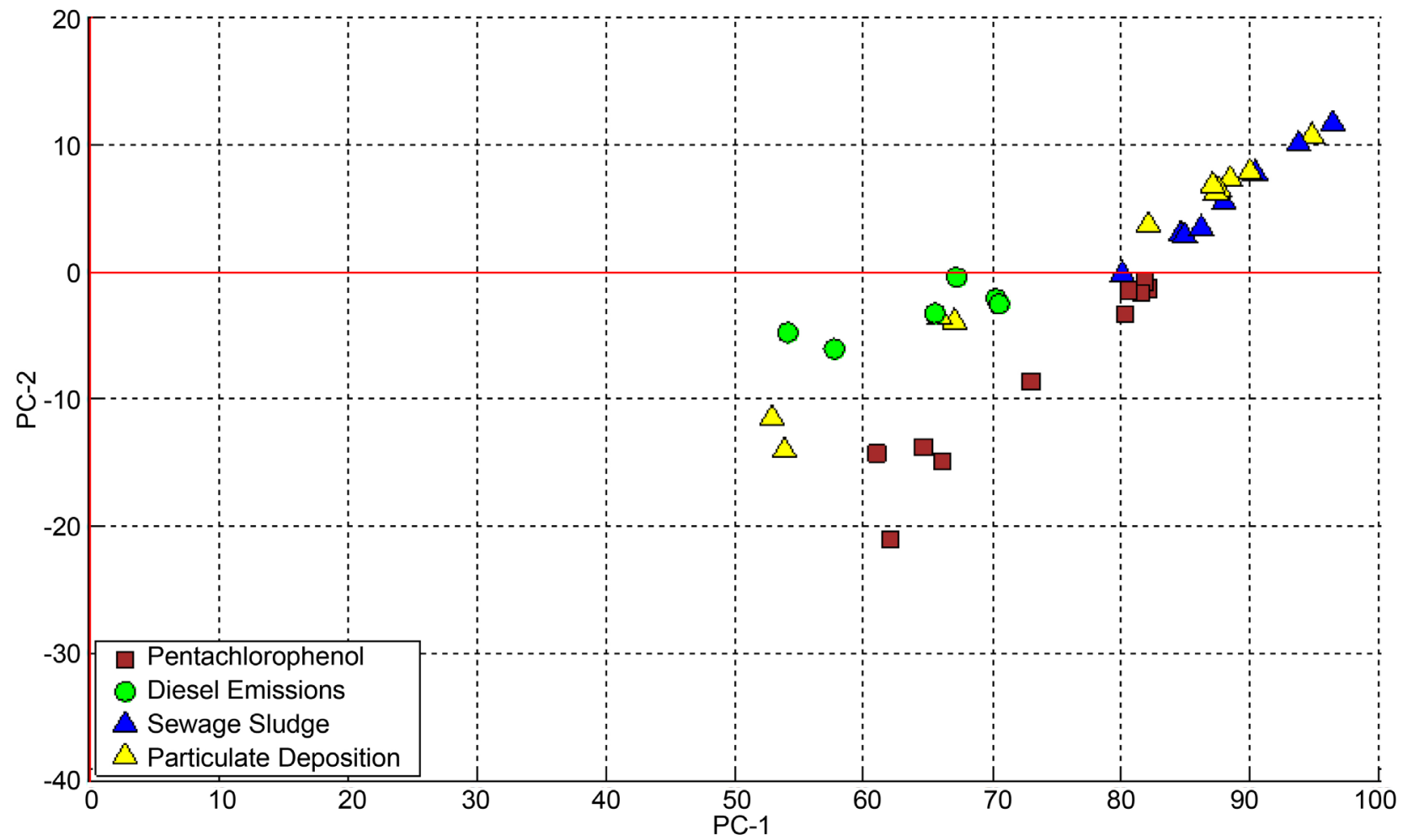

Sample Normalization/Log Transform/Autoscale

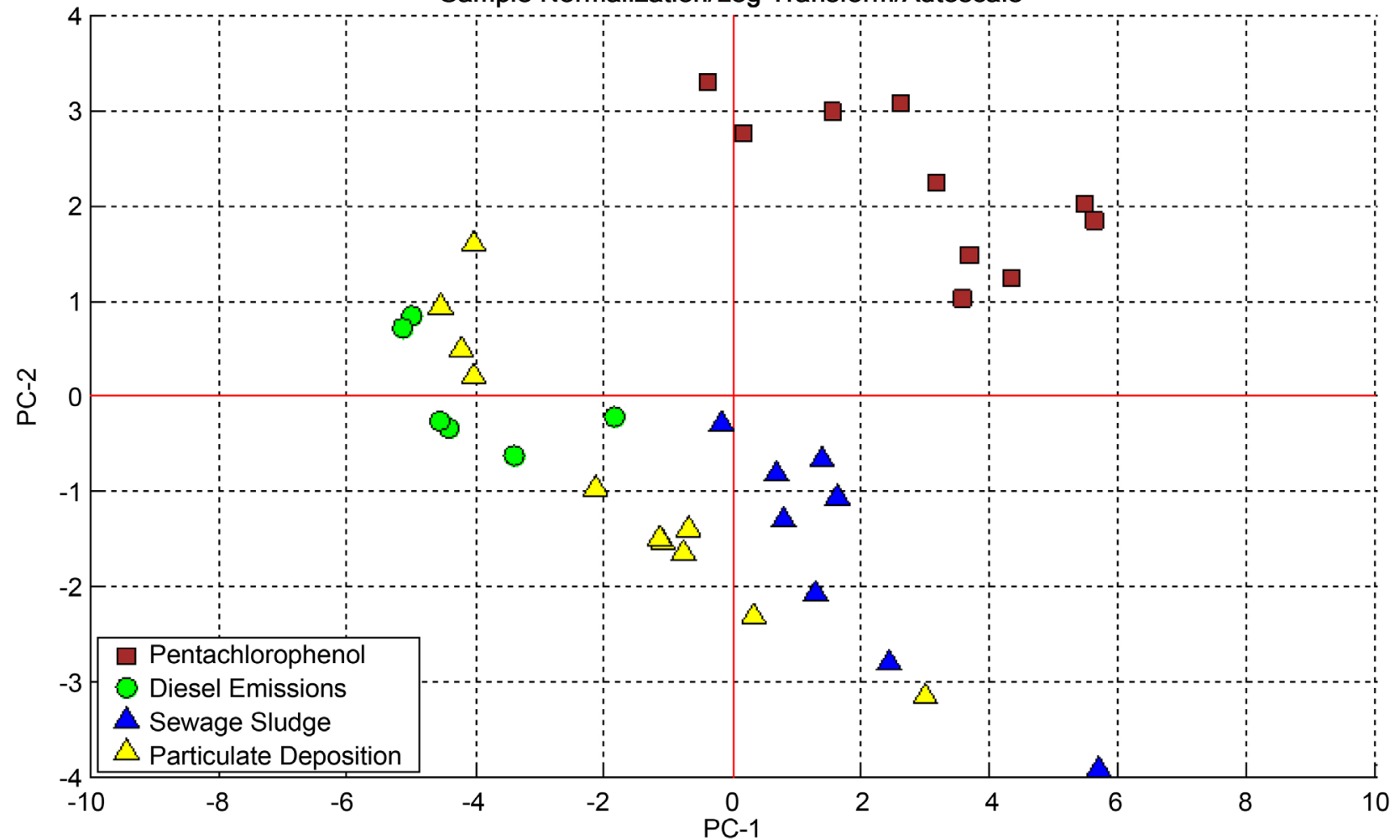

Figure 6. Scores plots from two PCA runs of a 17 PCDD/F congener data set with samples from four different source categories: PCP, diesel emissions, sewage sludge and particulate deposition. Data for the first PCA run (top panel) were sample normalized (percent-transform). Data for the second PCA (bottom panel) were transformed by percent, followed by a log transform, followed by mean-center/scaling (autoscale). Data were compiled from [14] [27] [28] [31] [32] [33] [34]. 
Table 3. Spearman rank correlation coefficients calculated between PCDD/F samples used in PCA (Figure 6).

\begin{tabular}{|c|c|c|c|c|c|c|c|c|c|c|}
\hline Source Category/Sample [citation] & PCP-01 & PCP-02 & PCP-03 & PCP-04 & PCP-05 & PCP-06 & PCP-07 & PCP-08 & PCP-09 & PCP-10 \\
\hline PCP-01 Soil S-5 [14] & 1.00 & 0.99 & 0.99 & 0.93 & 0.96 & 0.95 & 0.95 & 0.99 & 0.99 & 0.96 \\
\hline PCP-02 Soil S-9 [14] & 0.99 & 1.00 & 0.99 & 0.95 & 0.97 & 0.95 & 0.96 & 1.00 & 1.00 & 0.97 \\
\hline PCP-03 Soil S-3 [14] & 0.99 & 0.99 & 1.00 & 0.94 & 0.96 & 0.95 & 0.96 & 0.98 & 0.99 & 0.97 \\
\hline PCP-04 Railway Tie DS00000417 [27] & 0.93 & 0.95 & 0.94 & 1.00 & 0.99 & 0.95 & 0.95 & 0.95 & 0.95 & 0.92 \\
\hline PCP-05 Railway Tie DS00000418 [27] & 0.96 & 0.97 & 0.96 & 0.99 & 1.00 & 0.97 & 0.96 & 0.97 & 0.98 & 0.95 \\
\hline PCP-05 Power Pole DM00000422 [27] & 0.95 & 0.95 & 0.95 & 0.95 & 0.97 & 1.00 & 1.00 & 0.95 & 0.96 & 0.95 \\
\hline PCP-06 Power Pole RA00000422 [27] & 0.95 & 0.96 & 0.96 & 0.95 & 0.96 & 1.00 & 1.00 & 0.96 & 0.96 & 0.96 \\
\hline PCP-07 Power Pole 1 yr after treatment [28] & 0.99 & 1.00 & 0.98 & 0.95 & 0.97 & 0.95 & 0.96 & 1.00 & 1.00 & 0.98 \\
\hline PCP-08 Power Pole 4 yrs after treatment [28] & 0.99 & 1.00 & 0.99 & 0.95 & 0.98 & 0.96 & 0.96 & 1.00 & 1.00 & 0.98 \\
\hline PCP-09 Power Pole 11 yrs after treatment [28] & 0.96 & 0.97 & 0.97 & 0.92 & 0.95 & 0.95 & 0.96 & 0.98 & 0.98 & 1.00 \\
\hline Diesel Emissions 6 [34] & 0.47 & 0.53 & 0.48 & 0.63 & 0.57 & 0.53 & 0.53 & 0.54 & 0.52 & 0.50 \\
\hline Diesel Emissions 9 [34] & 0.64 & 0.68 & 0.62 & 0.69 & 0.68 & 0.63 & 0.63 & 0.68 & 0.69 & 0.66 \\
\hline Diesel Emissions 5 [34] & 0.60 & 0.65 & 0.58 & 0.64 & 0.64 & 0.53 & 0.54 & 0.65 & 0.65 & 0.59 \\
\hline Diesel Emissions 3 [34] & 0.46 & 0.50 & 0.45 & 0.60 & 0.56 & 0.51 & 0.51 & 0.51 & 0.50 & 0.51 \\
\hline Diesel Emissions 8 [34] & 0.65 & 0.68 & 0.65 & 0.70 & 0.67 & 0.65 & 0.64 & 0.65 & 0.66 & 0.60 \\
\hline Diesel Emissions 10 [34] & 0.79 & 0.79 & 0.79 & 0.74 & 0.77 & 0.73 & 0.72 & 0.76 & 0.79 & 0.73 \\
\hline Sewage Sludge A [31] & 0.67 & 0.71 & 0.65 & 0.71 & 0.69 & 0.73 & 0.71 & 0.68 & 0.69 & 0.67 \\
\hline Sewage Sludge B [31] & 0.72 & 0.74 & 0.70 & 0.67 & 0.67 & 0.66 & 0.64 & 0.70 & 0.71 & 0.62 \\
\hline Sewage Sludge E [31] & 0.71 & 0.74 & 0.69 & 0.72 & 0.70 & 0.71 & 0.69 & 0.71 & 0.71 & 0.65 \\
\hline Sewage Sludge G [31] & 0.72 & 0.74 & 0.69 & 0.70 & 0.69 & 0.68 & 0.66 & 0.72 & 0.72 & 0.65 \\
\hline Sewage Sludge H [31] & 0.69 & 0.71 & 0.68 & 0.67 & 0.67 & 0.69 & 0.68 & 0.69 & 0.69 & 0.65 \\
\hline Sewage Sludge K [31] & 0.65 & 0.68 & 0.64 & 0.73 & 0.69 & 0.64 & 0.63 & 0.65 & 0.65 & 0.59 \\
\hline Sewage Sludge L [31] & 0.82 & 0.84 & 0.82 & 0.85 & 0.84 & 0.86 & 0.85 & 0.82 & 0.82 & 0.80 \\
\hline Sewage Sludge N [31] & 0.63 & 0.67 & 0.61 & 0.67 & 0.65 & 0.57 & 0.55 & 0.64 & 0.65 & 0.56 \\
\hline Deposition-Hornisgrinde 10/92 [32] [33] & 0.42 & 0.46 & 0.44 & 0.56 & 0.50 & 0.43 & 0.43 & 0.44 & 0.44 & 0.40 \\
\hline Deposition-KA-Eggenstein 10/92-11/92 [32] [33] & 0.45 & 0.49 & 0.45 & 0.57 & 0.52 & 0.47 & 0.47 & 0.48 & 0.47 & 0.40 \\
\hline Deposition-KA-Eggenstein 11/92-12/92 [32] [33] & 0.64 & 0.67 & 0.65 & 0.71 & 0.67 & 0.67 & 0.66 & 0.63 & 0.64 & 0.60 \\
\hline Deposition-Goldscheuer 3/92-4/92 [32] [33] & 0.62 & 0.67 & 0.63 & 0.71 & 0.66 & 0.64 & 0.63 & 0.65 & 0.64 & 0.61 \\
\hline Deposition-Waiblingen 11/92-12/92 [32] [33] & 0.65 & 0.67 & 0.67 & 0.70 & 0.65 & 0.67 & 0.66 & 0.63 & 0.63 & 0.60 \\
\hline $\begin{array}{l}\text { Deposition-Karlsruhe-Mitte 10/92-11/92 [32] } \\
\text { [33] }\end{array}$ & 0.53 & 0.57 & 0.53 & 0.65 & 0.59 & 0.58 & 0.56 & 0.53 & 0.54 & 0.48 \\
\hline Deposition-Pforzheim-Mitte 4/92-6/92 [32] [33] & 0.52 & 0.57 & 0.54 & 0.66 & 0.60 & 0.52 & 0.51 & 0.55 & 0.54 & 0.47 \\
\hline Deposition-Pforzheim-Mitte 6/92-7/92 [32] [33] & 0.53 & 0.59 & 0.53 & 0.71 & 0.65 & 0.58 & 0.57 & 0.57 & 0.55 & 0.52 \\
\hline $\begin{array}{l}\text { Deposition-Karlsruhe Vogesenbrucke } \\
\text { 10/92-11/92 [32] [33] }\end{array}$ & 0.46 & 0.50 & 0.47 & 0.60 & 0.54 & 0.46 & 0.46 & 0.49 & 0.48 & 0.42 \\
\hline Deposition-Stuttgart 3/92-4/92 [33] & 0.59 & 0.64 & 0.60 & 0.73 & 0.66 & 0.62 & 0.62 & 0.62 & 0.62 & 0.57 \\
\hline Deposition-Stuttgart 6/92-7/92 [33] & 0.44 & 0.49 & 0.44 & 0.61 & 0.55 & 0.50 & 0.48 & 0.46 & 0.45 & 0.41 \\
\hline
\end{tabular}

most abundant, followed in turn by hepta, hexa, penta and tetra chlorinated congeners at progressively order-of-magnitude lower concentrations. This distinctive part of the PCP pattern is subtle, but is observed in PCP related congener profiles from multiple studies. The distinctive part of the congener pattern 
is within congeners that are orders of magnitude lower in concentration than OCDD, which has implications for the analytical methods necessary to recognize it. Very low detection limits are required. If for example, OCDD is present in a PCP impacted sample at $10,000 \mathrm{ng} / \mathrm{kg}$, one will need to employ an analytical method with detection limits in the 0.5 to $5 \mathrm{ng} / \mathrm{kg}$ range in order to detect levels of tetra chlorinated congeners necessary to distinguish that congener profile from non-PCP, OCDD dominated patterns. Twenty years ago (when studies suggesting that PCP had a congener profile similar to other sources was published) such low detection limits were uncommon. Today, they are routine.

Distinguishing this PCP congener profile also requires careful consideration of data visualization methods. Because the diagnostic lower chlorinated dioxin furans make up less than $1 \%$ of the total PCDD/F in PCP, it is very difficult to distinguish PCP from other OCDD dominated source patterns by inspection of bar-graphs with a linear y axis. Using a log-scale y axis, however, PCP profiles are obvious, and are not easily confused with those from other sources. In multivariate statistical analysis, the data transformations used prior to the analysis are crucial. Without proper normalization/scaling, the dominance of OCDD in different source patterns may drive the analysis and create an apparent similarity of samples on a scores plot. Because OCDD is often the dominant congener in $\mathrm{PCDD} / \mathrm{F}$ data sets, a "homogeneity of variance" transformation, such as an autoscale, is highly recommended for multivariate analysis of PCDD/F congener data [36].

\section{References}

[1] National Toxicology Program (NTP) (1989) Toxicology and Carcinogenesis Studies of Two Pentachlorophenol Technical-Grade Mixtures in B6C3F1 Mice. NTP Technical Report Series No. 349, U.S. Department of Health and Human Services.

[2] U.S. Environmental Protection Agency (1978) Report of the Ad Hoc Study Group on Pentachlorophenol Contaminants. Environmental Health Advisory Committee, Science Advisory Board, Report EPA/SAB/78/001, 29 December 1978.

[3] Monsanto Chemical Company (1951) Weed Control with Monsanto Santobrite and Santophen 20. St. Louis, MO.

[4] California Environmental Protection Agency (1998) Pentachlorophenol (PCP) Risk Characterization Document. 9 June 1998.

http://www.cdpr.ca.gov/docs/risk/rcd/pentachl.pdf

[5] Jensen, S. and Renberg, L. (1972) Contaminants in Pentachlorophenol: Chlorinated Dioxins and Predioxins. Ambio, 1, 62-65.

[6] Crummett, W.B. and Stehl, R.H. (1973) Determination of Chlorinated Dibenzo-p-Dioxins and Dibenzofurans in Various Materials. Environmental Health Perspectives, 5, 15-25.

[7] Firestone, D., Ress, J., Brown, N.L., Barron, R.P. and Damico, J.N. (1973) Determination of Polychlorodibenzo-p-Dioxins and Related Compounds in Commercial Chlorophenols. Journal of Association of Official Analytical Chemists, 55, 85-92.

[8] Plimmer, J.R. (1973) Technical Pentachlorophenol: Origin and Analysis of BaseInsoluble Contaminants. Environmental Health Perspectives, 5, 41-48.

[9] Hagenmaier, H. and Brunner, H. (1987) Isomerspecific Analysis of Pentachloro- 
phenol and Sodium Pentachlorophenate for 2,3,7,8-Substituted PCDD and PCDF at Sub-ppb Levels. Chemosphere, 16, 1759-1764.

https://doi.org/10.1016/0045-6535(87)90164-0

[10] Van den Berg, M., Birnbaum, L.S., Denison, M., De Vito, M., Farland, W., Feeley, M., Fiedler, H., Hakansson, H., Hanberg, A., Haws, L., Rose, M., Safe, S., Schrenk, D., Tohyama, C., Tritscher, A., Tuomisto, J., Tysklind, M., Walker, N. and Peterson, R.E. (2006) The 2005 World Health Organization Reevaluation of Human and Mammalian Toxic Equivalency Factors for Dioxins and Dioxin-Like Compounds. Toxicological Sciences, 93, 223-241. https://doi.org/10.1093/toxsci/kfl055

[11] SRC, Inc. (2009) Review of International Soil Levels for Dioxin. Prepared for U.S. Environmental Protection Agency Office of Superfund Remediation and Technology Innovation, Washington DC, 28 December 2009.

[12] Hayward, D.G., Petreas, M.X., Winkler, J.J., Visita, P., McKinney, M. and Stephens, R.D. (1996) Investigation of a Wood Treatment Facility: Impact on an Aquatic Ecosystem in the San Joaquin River, Stockton, CA. Archives of Environmental Contamination and Toxicology, 30, 30-39. https://doi.org/10.1007/BF00211326

[13] Dahlgren J, Warshaw R., Horsak R.D., Parker F.M., Takhar, H. (2003) Exposure Assessment of Residents Living near a Wood Treatment Plant. Environmental Research, 92, 99-109. https://doi.org/10.1016/S0013-9351(02)00064-6

[14] GeoTrans, Inc., AMEC, and Groundwater Insight (2003) Koppers Industries, Inc. Grenada Facility, Grenada, Mississippi. Complete Phase II RCRA Facility Investigation Report. Prepared for Beazer East, Inc. Pittsburgh, PA. GeoTrans. Rancho Cordova, CA.

[15] CH2MHill (1997) Remedial Investigation Report for the Wyckoff Soil and Groundwater Operable Units. Wyckoff/Eagle Harbor Superfund Site, Bainbridge Island, Washington DC. Prepared for U.S. Environmental Protection Agency, 13 June 1997. https://quicksilver.epa.gov/work/10/1064779.pdf

[16] Öberg, L.G. and Rappe, C. (1992) Biochemical Formation of PCDD/Fs from Chlorophenols. Chemosphere, 25, 49-52. https://doi.org/10.1016/0045-6535(92)90477-9

[17] Baker, J.I. and Hites, R.A. (2000) Is Combustion the Major Source of Polychlorinated Dibenzo-p-Dioxins and Dibenzofurans to the Environment? A Mass Balance Investigation. Environmental Science \& Technology, 34, 2879-2886. https://doi.org/10.1021/es9912325

[18] Hassanin, A., Lee, R.G.M., Johnston, A.E. and Jones, K.C. (2006) Reductions and Changing Patterns of Ambient PCDD/Fs in the UK: Evidence and Implications. Chemosphere, 65, 530-539. https://doi.org/10.1016/j.chemosphere.2006.01.032

[19] Holt E., Von der Recke, R., Vetter, W., Hawker, D., Alberts, V., Kuch, B., Weber, R. and Gaus, C. (2008) Assessing Dioxin Precursors in Pesticide Formulations and Environmental Samples as a Source of Octachlorodibenzo- $p$-Dioxin in Soil and Sediment. Environmental Science \& Technology, 42, 1472-1478.

https://doi.org/10.1021/es071687r

[20] Wenning, R.J., Paustenbach, D.J., Harris, M.A. and Bedbury, H. (1993) Principal Components Analysis of Potential Sources of Polychlorinated Dibenzo-p-Dioxin and Dibenzofuran Residues in Surficial Sediments from Newark Bay, New Jersey. Archives of Environmental Contamination and Toxicology, 24, 271-289. https://doi.org/10.1007/BF01128726

[21] Hagenmaier, H., Lindig, C. and She, J. (1994) Correlation of Environmental Occurrence of Polychlorinated Dibenzo-p-Dioxins and Dibenzofurans with Possible Sources. Chemosphere, 29, 2163-2174. https://doi.org/10.1016/0045-6535(94)90383-2 
[22] Cleverly, D., Schaum, J., Schweer, G., Becker, J. and Winters, D. (1997) The Congener Profiles of Anthropogenic Sources of Chlorinated Dibenzo-p-Dioxins and Chlorinated Dibenzofurans in the United States. Organohalogen Compounds, 32, 430-435.

[23] Cochran, J. (2016) Characterizing All 136 Tetra- to Octachlorinated Dioxins and Furans. Restek Technical Resources Library.

http://www.restek.com/Technical-Resources/Technical-Library/Environmental/env A030

[24] Schecter, A., Papke, O., Isaac, J., Hrimat, N.S., Neiroukh, F., Safi, J. and El-Nahhal, Y. (1997) 2,3,7,8-Chlorine Substituted Dioxin and Dibenzofuran Congeners in 2,4D, 2,4,5-T and Pentachlorophenol. Organohalogen Compounds, 32, 51-55.

[25] Wilkinson, J. (1997) Letter from John Wilkinson (Pentachlorophenol Task Force) to Matthew Lorber (U.S. EPA/ORD/NCEA). 7 February 1997. Pentachlorophenol Task Force, Washington DC.

[26] U.S. Environmental Protection Agency (2006) An Inventory of Sources and Environmental Releases of Dioxin-Like Compounds in the United States for the Years 1987, 1995, and 2000. Report EPA/600/P-03/002F, November 2006.

http://ofmpub.epa.gov/eims/eimscomm.getfile?p_download_id=523391

[27] Van Oostdam, J.C. and Ward, J.E.H. (1995) Dioxins and Furans in the British Columbia Environment. BC Environment, Environmental Protection Department, Victoria, BC, 3 April 1995.

[28] Lorber, M.N., Barton, R.G., Winters, D.L., Bauer, K.M., Davis, M. and Palausky, J. (2002) Investigation of the Potential Release of Polychlorinated Dioxins and Furans from PCP-Treated Utility Poles. Science of the Total Environment, 290, 15-39. https://doi.org/10.1016/S0048-9697(01)01051-8

[29] Masunaga, S., Takasuga, T. and Nakanishia, J. (2001) Dioxin and Dioxin-Like PCB Impurities in Some Japanese Agrochemical Formulations. Chemosphere, 44, 873 885. https://doi.org/10.1016/S0045-6535(00)00310-6

[30] Tondeur, Y., Nestrick, T., Silva, H.A., Vining, B. and Hart, J. (2010) Analytical Procedures for the Determination of Polychlorinated-p-Dioxins, Polychlorinated Dibenzofurans, and Hexachlorobenzene in Pentachlorophenol. Chemosphere, 80, 157-164. https://doi.org/10.1016/j.chemosphere.2010.04.001

[31] Clarke, B., Porter, N., Symons, R., Blackbeard, P.A. and Marriott, P. (2008) Dioxin-Like Compounds in Australian Sewage Sludge-Review and National Survey. Chemosphere, 72, 1215-1228. https://doi.org/10.1016/j.chemosphere.2008.01.076

[32] Wallenhorst, T., Krauß, P. and Hagenmaier, H. (1997) PCDD/F in Ambient Air and Deposition in Baden-Wurttemberg, Germany. Chemosphere, 34, 1369-1378. https://doi.org/10.1016/S0045-6535(97)00434-7

[33] Wallenhorst, T. (1996) Untersuchungen zur Verteilung und zum luftgetragenen Transport von Polyhalogenierten Dibenzo-p-dioxinen und Dibenzofuranen in Baden-Württemberg. Ph.D. Dissertation, University of Tubingen, Tubingen.

[34] Gertler, A.W., Sagebiel, J.C., Dippel, W.A. and Farina, R.J. (1998) Measurements of Dioxin and Furan Emission Factors from Heavy-Duty Diesel Vehicles. Journal of the Air \& Waste Management Association, 48, 276-278. https://doi.org/10.1080/10473289.1998.10463677

[35] Hagenmaier, H., Dawidowsky, V., Weber, U.B., Hutzinger, O., Schwind, K.H., Thoma, H., Essers, U., Buhler, U. and Greiner, R. (1990) Emission of Polyhalogenated Dibenzodioxins and Dibenzofurans from Combustion-Engines. Organohalogen Compounds, 2, 329-334.

[36] Johnson, G.W., Ehrlich, R., Full, W. and Ramos, S. (2015) Principal Components 
Analysis and Receptor Models in Environmental Forensics. In: Morrison, R. and Murphy, B., Eds., An Introduction to Environmental Forensics, 3rd Edition, Elsevier, Amsterdam, 609-653. https://doi.org/10.1016/b978-0-12-404696-2.00018-7

[37] WHO (1987) Environmental Health Criteria 71: Pentachlorophenol. International Programme on Chemical Safety, World Health Organization, Geneva, Switzerland, CH-1211.

[38] IRPTC (1983) Data Profile on Pentachlorophenol, Geneva, International Register of Potentially Toxic Chemicals, United Nations Environment Programme.

\section{Submit or recommend next manuscript to SCIRP and we will provide best} service for you:

Accepting pre-submission inquiries through Email, Facebook, LinkedIn, Twitter, etc. A wide selection of journals (inclusive of 9 subjects, more than 200 journals)

Providing 24-hour high-quality service

User-friendly online submission system

Fair and swift peer-review system

Efficient typesetting and proofreading procedure

Display of the result of downloads and visits, as well as the number of cited articles Maximum dissemination of your research work

Submit your manuscript at: http://papersubmission.scirp.org/

Or contact jep@scirp.org 